\title{
A Radiological Survey in Tailings: A Case Study of Rosterman Gold Mine, Western Kenya
}

\author{
Conrad Khisa Wanyama1, John Wanjala Makokha1, Fred Wekesa Masinde² \\ ${ }^{1}$ Department of Science, Technology and Engineering, Kibabii University, Bungoma, Kenya \\ ${ }^{2}$ Department of Physical Sciences, South Eastern Kenya University, Kitui, Kenya \\ Email:conradkhs@gmail.com, makokhajw@kibu.ac.ke,fmasinde@seku.ac.ke
}

How to cite this paper: Wanyama, C.K., Makokha, J.W. and Masinde, F.W. (2020) A Radiological Survey in Tailings: A Case Study of Rosterman Gold Mine, Western Kenya. Open Access Library Journal, 7: e6293.

https://doi.org/10.4236/oalib.1106293

Received: April 2, 2020

Accepted: May 10, 2020

Published: May 13, 2020

Copyright $\odot 2020$ by author(s) and Open Access Library Inc.

This work is licensed under the Creative Commons Attribution International License (CC BY 4.0).

http://creativecommons.org/licenses/by/4.0/

\section{(c) (i) Open Access}

\begin{abstract}
Thirty samples of tailing waste weighing $200 \mathrm{~g}$ were randomly collected from both active and inactive tunnels at the Rosterman gold mine site in western Kenya. The average activity concentration of the radionuclides $\left({ }^{40} \mathrm{~K},{ }^{232} \mathrm{Th}\right.$ and ${ }^{238} \mathrm{U}$ ) analyzed by the gamma-ray spectrometry in the tailing samples was 260 $\pm 14.29 \mathrm{~Bq} / \mathrm{Kg}$ for ${ }^{40} \mathrm{~K}, 118 \pm 8.25 \mathrm{~Bq} / \mathrm{Kg}$ for ${ }^{232} \mathrm{Th}$ and $81 \pm 3.63 \mathrm{~Bq} / \mathrm{Kg}$ for ${ }^{238} \mathrm{U}$. The corresponding radiological parameters for all the collected thirty tailing waste samples were determined from the specific mean activity concentrations. The average dose rate for all the samples was $54 \mathrm{nGy} / \mathrm{h}$. The average radium equivalent value was $262 \pm 12.04 \mathrm{~Bq} / \mathrm{Kg}$ with a range of $154 \pm$ $6.42 \mathrm{~Bq} / \mathrm{Kg}$ to $350 \pm 10.24 \mathrm{~Bq} / \mathrm{Kg}$. The average values of external and internal indices were $0.6 \pm 0.03 \mathrm{mSv} / \mathrm{y}$ and $0.7 \pm 0.04 \mathrm{mSv} / \mathrm{y}$ respectively. The average indoor and outdoor annual effective dose rates that were determined for this study were $0.3 \pm 0.02$ and $0.2 \pm 0.01$ respectively. Therefore, the tailing samples recorded doses and radiological indices below the world average permissible values. This implies that the radiation exposure to the miners and general public due to tailing wastes at Rosterman gold mine poses no significant health risk.
\end{abstract}

\section{Subject Areas}

Nuclear and Radiation Physics

\section{Keywords}

Tailing Samples, Rosterman Gold Mine, Gamma Ray Spectrometry, Radionuclides

\section{Introduction}

Natural radioactivity and the associated exposure due to gamma radiations de- 
pend on the geographical conditions and appear at different levels in the soil [1]. The specific levels are related to the type of rock from which the soil originates. Higher radioactivity levels are associated with igneous rocks such as granitic and silic rocks and lower levels with sedimentary rocks except Shale and Phosphate rocks [2]. Several surveys have shown that there are a few regions in the world that are known as high background radiation regions due to geology and geochemical effects that cause enhanced levels of terrestrial radiation [3].

The main sources of external gamma radiation are due to ${ }^{40} \mathrm{~K},{ }^{238} \mathrm{U}$ and ${ }^{232} \mathrm{Th}$ with their decay products [4]. ${ }^{226} \mathrm{Ra}$ and its daughter products are responsible for the major fraction of the internal dose received by humans from naturally occurring radionuclides [2]. Among the natural radionuclides, alpha and beta emitters are considered the most important with respect to potential internal radiation exposure to humans particularly through ingestion of food and water as approximately $20 \%$ of ${ }^{226} \mathrm{Ra}$ isotope and $12 \%$ of the lead isotopes which are the decay products of ${ }^{238} \mathrm{U}$ and ${ }^{232} \mathrm{Th}$ considered for this study reach the blood stream and are distributed to the whole body and follow the same metabolism as calcium [5]. The percentage distribution of annual intakes of Uranium and Thorium radionuclide decay series in diet ranges between $4 \%$ and $96 \%$ [6], as a result accumulation of these radionuclides has a vital health effects such as leukemia, bone cancer and increase in blood pressure [7]. The annual global average per caput dose from the natural background radiation is $2.42 \mathrm{mSv}$; this includes cosmic radiations, radon inhalation and terrestrial sources [8].

Gold mining plays a major role in the Kenya's economic growth and development. In western Kenya (Kakamega county) has done artisanal for a period of about forty years. Apart from being a relevant source of income for local and national economy, gold mining may be responsible for several environmentally harmful effects; including tailing waste dumping, soil erosion, landscape deterioration and pollution. During artisanal gold mining, gold is manually extracted from open pits using hand tools, dried and then crushed. The tailing wastes are then dumped without proper regulations which may pose radionuclides that are harmful to human life [9]. Mining has therefore been identified as one of the potential sources of exposure to naturally occurring radioactive materials [6]. As a result, it is necessary for base-line studies to be carried out prior to the commencement of mining activity and subsequent similar work to be done to ascertain the radioactivity levels of these radionuclides that arise due to mining activities.

The present study seeks to assess the concentration levels of the radionuclides in the tailing wastes from Rosterman gold mining site, Western Kenya so that information could be provided for future reference. The survey study focuses on the determination of activity concentration and radiological indices and dose rate values.

\section{Local Geology of the Study Area}

The present study was conducted in Western Kenya where the Rosterman gold 


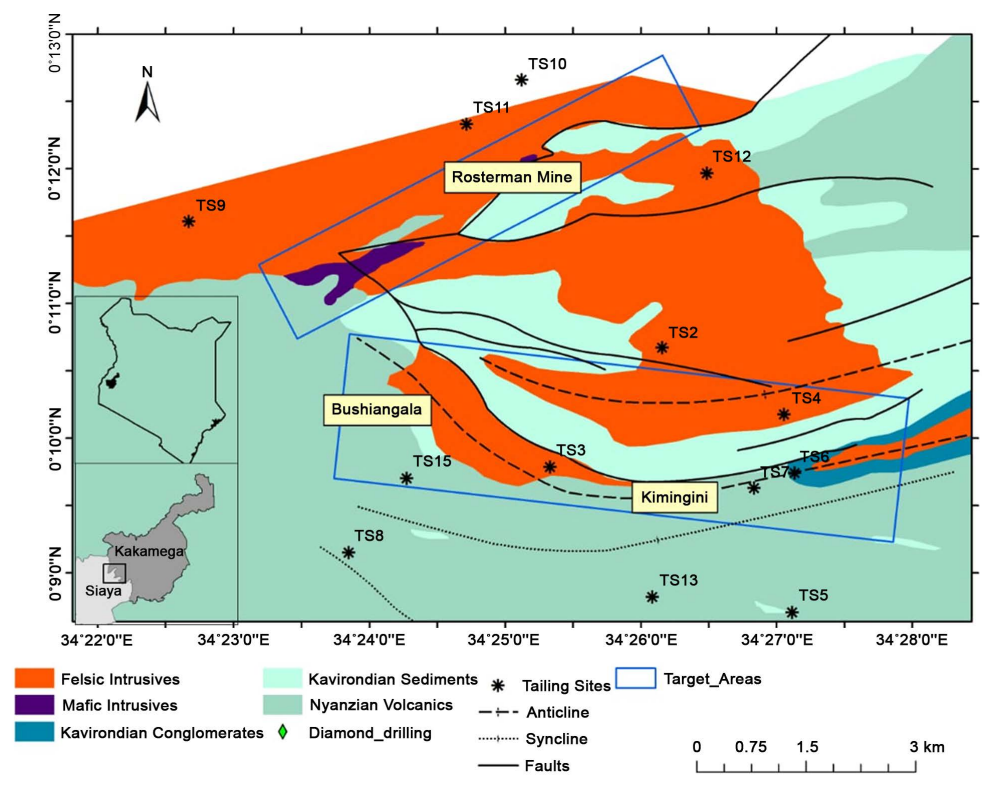

Figure 1. Map of Rosterman gold mine site [11].

mine site is situated. The Rosterman gold mine site is therefore situated in Lurambi sub-county, Kakamega municipality and $3.4 \mathrm{~km}$ from Kakamega town (Figure 1). Lurambi Sub County is one of the elective constituencies in Kenya situated in Kakamega County. It is bordered by Ikolomani constituency to the south and globally located at $0^{\circ} 17.569 \mathrm{~N}, 34^{\circ} 39.812 \mathrm{E}$ with approximately 420 $\mathrm{km}^{2}$. The population projection of Lurambi Sub County was estimated at 297,394 people according to the 2019 population census [10]. Figure 1 shows the Rosterman gold mine area where all the samples analyzed were collected and measurements taken using $\mathrm{NaI}(\mathrm{TI})$ gamma ray spectrometry.

The number of the houses in Lurambi Sub County is approximated at 65,121 households [10]. Currently, the population may have increased due to birth rates and increased job opportunities as a result of the presence of the Rosterman gold site. From Figure 1, two samples were collected from each tailing point for high statistical impact, as a result the study area had two targeted areas, mining site that consist of tailing tunnels and dumping site that consist of tailing wastes.

\section{Sample Collection and Preparation}

A total of thirty tailing waste samples were collected randomly from Rosterman gold mining site, western Kenya. Each sample was then collected at a depth of 50 $\mathrm{cm}$ and had a net weight of $0.2 \mathrm{~kg}$. Each raw sample was temporarily packed into $300 \mathrm{~g}$ plastic bottle well coded with date of collection, sample identification number and tunnel number. The plastic bottles were sealed to avoid leakage and contamination. The samples were then sun dried independently and ground to ensure homogeneity [3]. The samples were then sieved with a $2 \mathrm{~mm}$ mesh wire and then packed in water and air tight plastic containers and kept for at least twenty-eight days to allow ${ }^{232} \mathrm{Th}$ and ${ }^{226} \mathrm{Ra}$ attain secular equilibrium with their short-lived daughter radionuclides [12]. 


\section{Calibration of the Instrument}

Energy calibration is generally done to derive the relationship between peak position in the spectrum and the corresponding gamma ray photon energy [13]. In this study a $\mathrm{NaI}(\mathrm{TI})$ gamma ray spectrometer was used to determine the radionuclides of interest and their corresponding abundance. The calibration was done by the standard materials obtained from the international atomic energy agency whose activities are $4900 \mathrm{~Bq} / \mathrm{Kg}$ for $\mathrm{RG} \cdot \mathrm{U}^{-1}, 3280 \mathrm{~Bq} / \mathrm{Kg}$ for $\mathrm{RG} \cdot \mathrm{Th}^{-1}$ and $13,400 \mathrm{~Bq} / \mathrm{Kg}$ for $\mathrm{RG} \cdot \mathrm{K}^{-1}$ [14]. Two tailing samples were run per day for a live time of 480 minutes each. Due to the assumption that the radionuclides of interest and their decay daughters had attained secular equilibrium, the activity concentration of ${ }^{40} \mathrm{~K}$ was determined from a photo peak of $1460 \mathrm{KeV},{ }^{214} \mathrm{Bi}$ at a gamma line of $609 \mathrm{KeV},{ }^{232} \mathrm{Th}$ at a gamma line of $2615 \mathrm{KeV}$ and ${ }^{238} \mathrm{U}$ at a gamma line of $1765 \mathrm{KeV}$ [15].

\section{Results and Discussion}

\subsection{Specific Activity Concentration}

The analytical Equation (1) [16] was used to determine the specific activity concentrations of the three radionuclides $\left({ }^{40} \mathrm{~K},{ }^{232} \mathrm{Th}\right.$ and $\left.{ }^{238} \mathrm{U}\right)$ and the mean average activity concentration tabulated as shown in Table 1.

$$
A_{c}=\frac{N_{D}}{p \cdot n \cdot M}
$$

where $A_{c}$ is the specific activity concentration for a tailing sample in $\mathrm{Bq} / \mathrm{Kg}, N_{D}$ is the net count rate for a particular gamma ray energy, $E, p$ is the emission probability for gamma ray transition energy, $E, n$ is the detection efficiency at particular gamma ray energy, $E$ and $M$ is the tailing sample mass in $\mathrm{Kg}$.

In general, ${ }^{40} \mathrm{~K}$ reported higher mean activity concentration in the collected tailing samples than ${ }^{232} \mathrm{Th}$ and ${ }^{238} \mathrm{U}$ as presented in Table 1 . This was attributed by presence of minerals such as silicate in the sampled tailings [17]. The mean activity concentration of ${ }^{232} \mathrm{Th}$ and ${ }^{238} \mathrm{U}$ were higher than the worlds average values of $45 \mathrm{~Bq} / \mathrm{Kg}$ and $33 \mathrm{~Bq} / \mathrm{Kg}$ respectively [6]. These values were higher due to the change in the minerals components of the tailings as a result of difference in the depth of the tunnels [18]. Figure 2 compares ${ }^{40} \mathrm{~K}$ activity concentration in the tailing samples collected from Rosterman gold mine site.

From Figure 2, all the samples collected registered a mean activity concentration that was less than the world's average value of $400 \mathrm{~Bq} / \mathrm{Kg}$ [6]. The wider

Table 1. Mean average activity concentration of ${ }^{238} \mathrm{U},{ }^{232} \mathrm{Th}$ and ${ }^{40} \mathrm{~K}$ for the tailing samples collected at Rosterman gold mine site.

\begin{tabular}{cc}
\hline Radionuclide & $\boldsymbol{A}_{c}$ for Radionuclides \\
\hline${ }^{40} \mathrm{~K}$ & $260 \pm 14.29$ \\
${ }^{232} \mathrm{Th}$ & $118 \pm 8.25$ \\
${ }^{238} \mathrm{U}$ & $81 \pm 3.63$ \\
\hline
\end{tabular}




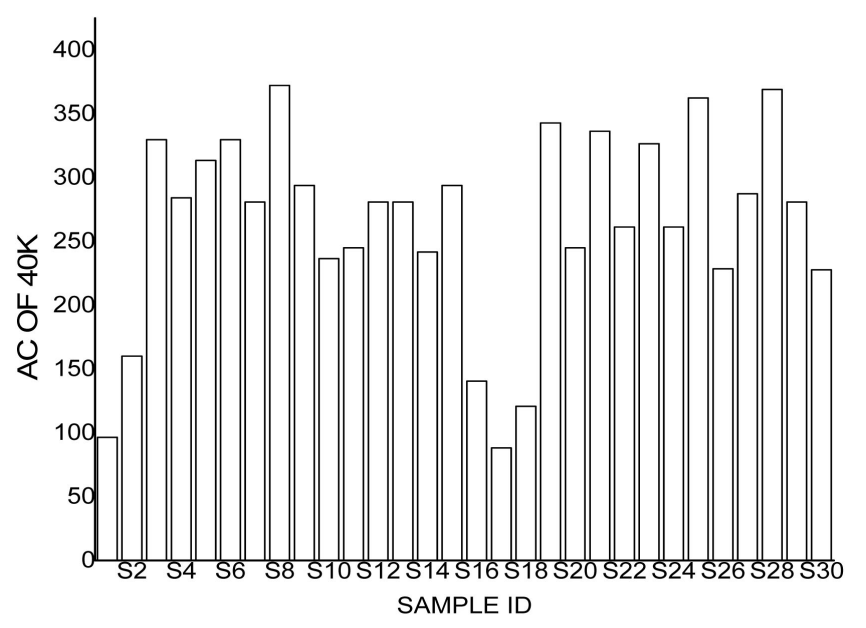

Figure $2 .{ }^{40} \mathrm{~K}$ (Potassium-40) activity concentration in tailing waste samples collected at Rosterman gold mining site.

variation in the activity concentration of ${ }^{40} \mathrm{~K}$ in the thirty collected samples was as a result of non-uniform distribution of the radionuclide in the rocks or the tailing wastes (Figure 2). However, the mean values of ${ }^{40} \mathrm{~K},{ }^{232} \mathrm{Th}$ and ${ }^{238} \mathrm{U}$ registered from the collected tailing samples were far below the exemption levels of $1000 \mathrm{~Bq} / \mathrm{Kg}$ for ${ }^{232} \mathrm{Th}$ and ${ }^{238} \mathrm{U}$ and $100,000 \mathrm{~Bq} / \mathrm{Kg}$ for ${ }^{40} \mathrm{~K}[19]$.

\subsection{Dose Rates}

The absorbed dose rate, ADR (nGy.h $\mathrm{h}^{-1}$ ) evaluated in air $1 \mathrm{~m}$ above the ground from various sampling points was done by converting specific activity concentration to absorbed dose rate using the conversion factors of $0.043,0.662$ and 0.427 for ${ }^{40} \mathrm{~K},{ }^{232} \mathrm{Th}$ and ${ }^{226} \mathrm{Ra}$ respectively [5]. To determine the annual individual's total risk, the absorbed dose rate was then converted to annual effective dose rate $\left(\mathrm{mSv} \cdot \mathrm{y}^{-1}\right)$ using guidelines for indoor and outdoor exposures [2]. The indoor annual effective dose rate ranged between $0.1 \pm 0.01$ and $0.4 \pm 0.02 \mathrm{mSv} / \mathrm{y}$ with an average annual effective dose rate of $0.3 \pm 0.01 \mathrm{mSv} / \mathrm{y}$ for all the collected tailing samples. This was below the global average value of $0.41 \mathrm{mSv} / \mathrm{y}$ [20]. The outdoor annual effective dose rate registered had a minimum value of $0.1 \pm 0.00 \mathrm{mSv} / \mathrm{y}$ and a maximum value of $0.3 \pm 0.01 \mathrm{mSv} / \mathrm{y}$ with an average value of $0.2 \pm 0.01 \mathrm{mSv} / \mathrm{y}$. This is still below the world average value of $0.48 \mathrm{mSv} / \mathrm{y}$ [21]. Hence the radiations exposure from tailing wastes at Rosterman gold mine poses no radiological health risk to the miners and the general public. Figure 3 shows the comparison between the annual effective dose rates

By comparison, the results of the annual effective dose rate in this research compare well with the range of annual effective dose rate values reported for other countries [6] as well as results from similar studies carried out in other gold mining sites such as Ghana [22]. From Figure 3, the values obtained for indoor annual effective dose $r$ ate were higher than the outdoor annual effective dose rate, this is due time that is spend by the miners and general public indoor is higher as compared to outdoor. All the samples therefore had annual effective 
dose rates below the permissible limits (Figure 3); hence the radiation exposure from the tailing samples poses no significant health risk to the population around Rosterman gold mine.

\subsection{Radiological Hazard Indices}

The radiological risk exposure by the radionuclides in the tailing samples at Rosterman gold mining site was estimated by the respective analytical equations [23]. Higher values of the radiological hazard indices were reported by sample number 27 as a result of non-uniform distribution of the primordial radioisotopes in the crustal structure. The radiological hazard indices such as radium equivalent, varied from one tailing sample to another indicating that there is non-uniform crustal distribution of natural radionuclides. The hazard indices (internal hazard index and external hazard index) and radium equivalent average values obtained from the collected tailing samples were tabulated in Table 2 .

The average radium equivalent was below the global permissible limit of 370 $\mathrm{Bq} / \mathrm{Kg}$ as shown in Table 2 [25], while internal hazard index and external hazard index were also below the global permissible limit of a unit [20]. Therefore, the radiation exposure to the public due to tailing wastes at Rosterman gold mine has insignificant health implication.

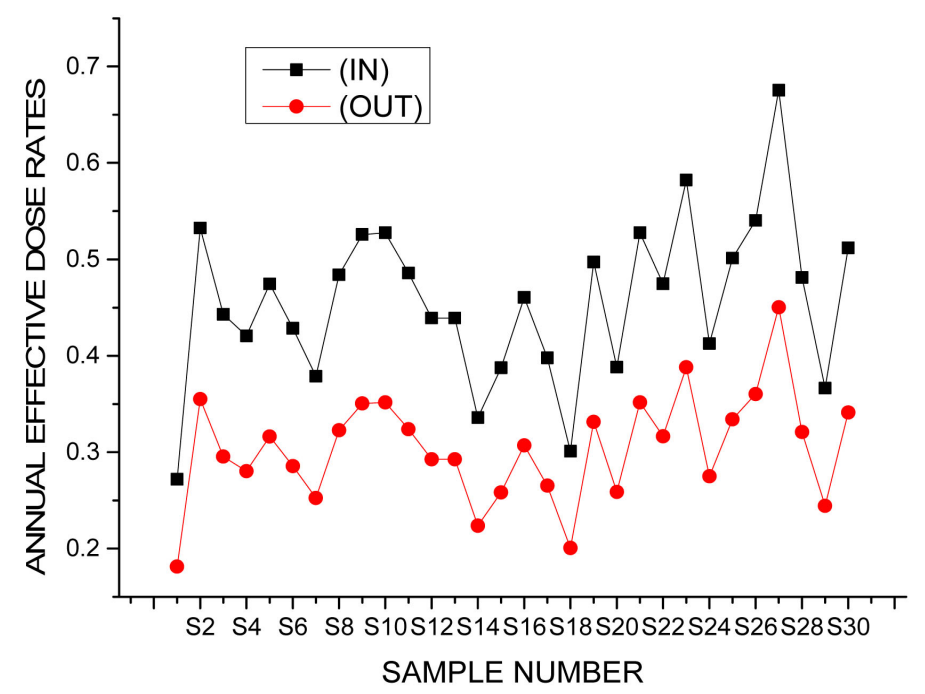

Figure 3. Comparison between indoor annual effective dose rate and outdoor annual effective dose rate for this work.

Table 2. The mean values of radium equivalent and the hazard indices of the tailing samples collected from Rosterman gold mine site.

\begin{tabular}{ccc}
\hline Indices & Study average value & Global permissible value \\
\hline Internal hazard (Hin) & $0.7 \pm 0.04 \mathrm{mSv} / \mathrm{y}$ & A unit [21] \\
External hazard (Hex) & $0.6 \pm 0.03 \mathrm{mSv} / \mathrm{y}$ & A unit [24] \\
Radium equivalent (Raeq) & $262 \pm 12.04 \mathrm{~Bq} / \mathrm{Kg}$ & $370 \mathrm{~Bq} / \mathrm{Kg}[6]$ \\
\hline
\end{tabular}




\section{Conclusion}

The concentration levels of natural radioactivity have been determined for all the collected tailing waste samples. Very few samples registered high levels of radioactivity concentrations due to non-uniform distribution of the primordial radionuclides in the crustal structure. However, the internal hazard index and external hazard index were below the global permissible or safety limit of $1 \mathrm{mSv} / \mathrm{y}$. The average radium equivalent was also below the world agreed value of 370 $\mathrm{Bq} / \mathrm{Kg}$ and therefore the tailing wastes have insignificant exposure risk to the miners at the gold mining site. Similar studies need to be done for several upcoming tunnels to monitor trends in the tailing's radioactivity concentration levels.

\section{Acknowledgements}

This research was carried out with the cooperation and support of the local residents of Rosterman gold mine site during the collection of the samples. Department of Science, Technology and Engineering at Kibabii University for provision of laboratory equipment's for sample collection and preparation. Kenyatta University, specifically the department of PHYSICS for providing the equipment for sample analysis (gamma ray spectrometry). I gratefully thank Dr. John W. Makokha in the department of Science, Technology and Engineering of Kibabii University for his professional contributions in this study. I also appreciate Dr. Fred W. Masinde for support and linking me to the Open Access Library Journal.

\section{Conflicts of Interest}

The authors declare no conflict of interest regarding publication of this paper.

\section{References}

[1] Faanu, A., Lawluvi, H., Kpeglo, D.O., Darko, E.O., Emi-Reynolds, G., Awudu, R., Adukpo, O.K., Kansaana, C., Ali, I.D., Agyeman, B., Agyeman, L. and Kpodzro, R. (2013) Assessment of Natural and Anthropogenic Radioactivity Levels in Soils, Rocks, and Water in the Vicinity of Chirano Gold Mine in Ghana. Radiation Protection Dosimetry, 158, 87-99. https://doi.org/10.1093/rpd/nct197

[2] Mam, U. (2007) Gamma-Ray Spectroscopic Analysis of Selected Samples from the Nile River Sediments in Upper Egypt. Radiation Protection Dosimetry, 123, 215-220. https://doi.org/10.1093/rpd/ncl103

[3] Kamunda, C., Mathuthu, M. and Madhuku, M. (2016) An Assessment of Radiological Hazards from Gold Mine Tailings in the Province of Gauteng in South Africa. International Journal of Environmental Research and Public Health, 13, 138. https://doi.org/10.3390/ijerph13010138

[4] Faanu, A., Adukpo, O.K., Tettey-Larbi, L.H., Kpeglo, D.O., Darko, E.O., Emi-Reynolds, G., Awudu, R.A., Kansaana, C., Amoah, P.A., Efa, A.O., Ali, I.D., Agyeman, B., Agyeman, L. and Kpodzro, R. (2016) Natural Radioactivity Levels in Soils, Rocks, and Water at a Mining Concession of Perseus Gold Mine and Surrounding Towns in the Central Region of Ghana. Springerplus, 5, 98. 
https://doi.org/10.1186/s40064-016-1716-5

[5] UNSCEAR (2008) United Nations Scientific Committee on the Effects of Atomic Radiation, Sources, and Effects of Ionizing Radiation. Report to General Assembly, with Scientific Annexes United Nations. United Nations, New York.

[6] UNSCEAR (2017) Sources and Effects of Ionizing Radiation. Report to General Assembly, with Scientific Annexes. United Nations, New York.

[7] Tettey-Larbi, L., Darko, E.O., Schandorf, C., Appiah, A.A., Sam, F., Faaanua, A., Okoh, D.K., Lawluvi, H., Agyeman, B.K., Kansaana, C., Amoah, P.A., Osei, R.K., Agalga, R. and Osei, S. (2013) Gross Alpha and Beta Activity and Annual Committed Effective Doses Due to Natural Radionuclides in Some Medicinal Plants Commonly Used in Ghana. International Journal of Science \& Technology, 3, 217-229.

[8] Ajithra, A. and Shanthi, G. (2016) Assessment of Beach sand Using Gamma Ray Spectrometer in Thiruvananthapuram District, Kerala of South India. International Journal of Technology \& Engineering, 5, 56-69.

https://doi.org/10.21013/jte.v5.n3.p2

[9] Odumo, B.O., Nanos, N., Carbonell, G., Torrijos, M., Patel, J.P. and Rodríguez Martín, J.A. (2018) Artisanal Gold-Mining in a Rural Environment: Land Degradation in Kenya. Land Degradation and Development, 29, 3285-3293. https://doi.org/10.1002/ldr.3078

[10] Kenya National Bureau of Statistics (2009) Population of Lurambi Sub-County. https://www.knbs.or.ke

[11] Independent Electoral and Boundaries Commission (2013) Map of Rosterman Gold Mine, Lurambi Sub-County, Kakamega County, Kenya.

[12] Matsitsi, M.S., Linturi, J.M., Kebwaro and Maweu, M.O. (2019) Effects of Seasonal Change on the Levels of Geogenic Radionuclides in Sand and Rocks from Tyaa River Deposit in Kitui County. International Journal of Fundamental Physical Sciences, 9, 14-19. https://doi.org/10.14331/ijfps.2019.330124

[13] Kebwaro, M.J. (2009) Gamma Ray Spectrometry Analysis of the Surface Soil around Mrima Hill, Kenya Using NaI (TI) Detector and Decomposition Technique. M.Sc. Thesis, Kenyatta University, Nairobi.

[14] IAEA (2010) Handbook of Parameter Values for the Prediction of Radionuclide Transfer in Terrestrial and Freshwater Environments. International Atomic Energy Agency.

[15] Samuel, O. (2015) Radiometric Survey and Estimation of Radiation from Archean Rocks: A Case Study of the Migori Gold Belt Complex, Kenya. M.Sc., Physics Kenyatta University, Nairobi.

[16] Quindos, L.S., Fernandez, P.L. and Soto, J. (1987) Building Material as a Source of Exposure in Houses. Indoor Air, 87, 365.

[17] Fujiyoshi, R. and Sawamura, S.J. (2004) Mesoscale Variability of Vertical Profiles of Environmental Radionuclides $\left({ }^{40} \mathrm{~K},{ }^{226} \mathrm{Ra},{ }^{210} \mathrm{~Pb}\right.$ and $\left.{ }^{137} \mathrm{Cs}\right)$ in Temperate Forest Soils in Germany. Science of the Total Environment, 320, 177-188. https://doi.org/10.1016/j.scitotenv.2003.08.007

[18] Kinyua, R., Atambo, V.O. and Ongeri, R.M. (2011) Activity Concentrations of ${ }^{40} \mathrm{~K}$, ${ }^{232} \mathrm{Th}$ and ${ }^{228} \mathrm{Ra}$ and Radiation Exposure of Tabaka Soapstone Quarries of the Kisii Region, Kenya. African Journal of Environmental Science and Technology, 5, 682-688.

[19] IAEA (1996) International Basic Safety Standards for Protection against Ionizing Radiation and for the Safety of Radiation Sources, Safety Series No. 115. IAEA, Vienna. 
[20] ICRP (1991) Annual Limits on the Intake of Radionuclides by Workers Based on 1990 Recommendations. International Commission of Radiological Protection 66. Annals of the ICRP, 21, 1-41.

[21] ICRP (2007) 2006 Recommendations of the International Commission on Radiological Protection. ICRP Publication No. 103, Pergamon Press, Oxford.

[22] Darko, E.O., Faanu, A., Razak, A., Emi-Reynolds, G., Yeboah, J., Oppon, O.C. and Akaho, E.H.K. (2010) Public Exposure Hazards Associated with Natural Radioactivity in Open-Pit Mining in Ghana. Radiation Protection Dosimetry, 138, 45-51. https://doi.org/10.1093/rpd/ncp181

[23] Lu, X.W., et al. (2005) Specific Activity and Hazards of Archeozoic-Cambrian Rock Samples Collected from the Weibei Area of Shaanxi, China. Radiation Protection Dosimetry, 118, 352-359. https://doi.org/10.1093/rpd/nci339

[24] Higgy, R., El-Tahawy, M., Abdel-Fattah, A. and Al-Akabawy, U.J. (2000) Radionuclide Content of Building Materials and Associated Gamma Dose Rates in Egyptian Dwellings. Journal of Environmental Radioactivity, 50, 253-261.

https://doi.org/10.1016/S0265-931X(00)00017-5

[25] El-Taher, A. and Al-Zahrani, J. (2014) Radioactivity Measurements and Radiation Dose Assessments in Soil of Al-Qassim Region, Saudi Arabia. The Vicinity of Chirano Gold Mine in Ghana. Radiation Protection Dosimetry, 158, 87-99. 